\title{
Improvement of Hepatic and Extrahepatic Complications from Chronic Hepatitis C After Antiviral Treatment: A Retrospective Analysis of German Sickness Fund Data
}

\author{
Michael R. Kraus · Henning Kleine - Stefanie Thönnes •
}

Marc Pignot · Yuri Sanchez Gonzalez

Received: May 23, 2018 / Published online: June 19, 2018

(C) The Author(s) 2018

\section{ABSTRACT}

Introduction: German data regarding the economic burden of chronic hepatitis $\mathrm{C}(\mathrm{CHC})$ and potential benefits of $\mathrm{CHC}$ treatment are limited. To address this issue, we evaluated the role of treatment in mitigating the economic burden of hepatic and extrahepatic complications (EHCs) from $\mathrm{CHC}$ virus infection in Germany.

Methods: This retrospective, cross-sectional study used claims data from the Betriebskrankenkasse German sickness fund (2007-2014) to assess the medical costs of hepatic complications and EHCs, including

Enhanced digital features To view enhanced digital features for this article go to https://doi.org/10.6084/ m9.figshare.6391541.

M. R. Kraus

Department of Internal Medicine II, Academic

Hospital Altötting-Burghausen, Burghausen,

Germany

H. Kleine

AbbVie Deutschland GmbH \& Co. KG, Wiesbaden,

Germany

S. Thönnes

Team Gesundheit GmbH, Essen, Germany

M. Pignot

Kantar Health, Munich, Germany

Y. Sanchez Gonzalez ( $\triangle)$

AbbVie Inc., Mettawa, IL, USA

e-mail: Yuri.SanchezGonzalez@AbbVie.com conditions that are prevalent and behavioral factors associated with CHC. All-cause costs, medical costs related to hepatic and EHCs, and CHC-related and non-CHC-related pharmacy costs (adjusted to the 2016 euro rate) were calculated and compared between CHC patients' treated $(n=1714)$ and untreated time $(n=7124)$ and CHC patients that initiated treatment early (i.e., without cirrhosis; $n=1552$ ) vs. late (i.e., with cirrhosis; $n=162$ ).

Results: CHC treatment was associated with an average adjusted savings of $€ 1885$ in annual allcause medical costs per patient, with a significant proportion attributed to EHC-related cost savings (adjusted difference, $€ 1363 ; P<0.01$ ). Although initiating $\mathrm{CHC}$ treatment early was economically beneficial compared with initiating treatment late, the total cost savings were not significantly different (annual average adjusted difference, $€ 3831 ; P=0.27$ ). However, nearly $60 \%$ of these savings were EHC related (adjusted difference, $€ 2255 ; P<0.01$ ).

Conclusion: CHC is associated with a significant economic burden in Germany, largely due to EHCs. Antiviral treatment may reduce the burden of $\mathrm{CHC}$ and result in significant cost savings, even when initiated at earlier stages of liver disease.

Funding: AbbVie Inc.

Keywords: Cirrhosis; Costs; Early treatment; Extrahepatic manifestations; Fibrosis; Hepatitis $\mathrm{C}$ virus; Liver disease 


\section{INTRODUCTION}

Hepatitis $\mathrm{C}$ virus (HCV) infection is a major health burden in Europe, reportedly affecting 14 million people in the WHO European region [1] and 2.6 million individuals in Western Europe [2]. While there is a paucity of data estimating the prevalence of $\mathrm{HCV}$ infection in Germany specifically, a 2013 study reported the overall prevalence of antibodies against HCV in the German population to be $0.3 \%$, similar to the prevalence estimated 10 years prior $(0.4 \%)$ [3]. Furthermore, the estimated diagnosis rate among those living with $\mathrm{HCV}$ is $57 \%$ [4].

Acute HCV infection is typically asymptomatic and often remains undiagnosed, with up to $85 \%$ of acutely infected individuals developing chronic hepatitis $\mathrm{C}$ (CHC) virus infection [5]. HCV infection presents with hepatic complications such as cirrhosis, hepatocellular carcinoma, and liver failure [6], apart from extrahepatic complications (EHCs) [7], which affect other organ systems, causing progressive illness and possible death [8]. These include common and well-studied EHCs, such as mixed cryoglobulinemia, depression, and type 2 diabetes mellitus (T2DM) [7], apart from others such as cryoglobulinemic vasculitis, B cell non-Hodgkin lymphoma, arthralgia, immune thrombocytopenia, renal impairment, fatigue, cognitive impairment, cancer, and cardiovascular disorders [9].

Beyond the direct burden of $\mathrm{HCV}$, other diseases, such as Parkinson's disease [10], behavioral and mental disorders due to psychoactive substance use [11], cardiovascular disorders [12], and non-hepatic malignancies [13], also impact the overall burden associated with CHC. A recent systematic review has shown that HCV-infected patients have approximately 35\% higher risk of Parkinson's disease compared with patients without HCV [10], while substance abuse contributes to viral exposure due to usage of contaminated needles [11].

Complications resulting from HCV infection are associated with substantial healthcare costs [14]. Economic modeling showed that the cost of extrahepatic manifestations (EHM) in Germany was $€ 1247$ per patient per year (PPPY), amounting to a total annual cost of $€ 301.9$ million [15]. Moreover, treatment costs increase incrementally according to disease stage, with patients requiring liver transplants spending more than patients with mild disease [14]. To quickly reduce HCV progression, global treatment guidelines encourage the use of newer, all-oral, direct-acting antiviral (DAA) regimens for $\mathrm{HCV}$ treatment rather than interferon-based regimens because of the former's higher sustained virologic response (SVR) at $>90 \%$, shorter treatment duration, and better tolerability [5]. Based on model estimates, DAA regimens could provide substantial shortand long-term benefits to patients and reduce the overall economic burden of HCV on the healthcare system. However, there is limited evidence from actual clinical practice on the extent to which these benefits compare with the up-front costs of treatment $[16,17]$. A recent Japanese study reported that utilizing DAAs avoided approximately $€ 8968$ in per-patient complication costs [18]. In India, too, DAA usage was tied to cost-savings for both non-cirrhotic $(€ 446)$ and cirrhotic $(€ 1205)$ patients [19]. Moreover, after taking the SVR rate and treatment duration into consideration, the cost per SVR for DAAs was found to be cheaper than that of interferon-based regimens [20].

$\mathrm{HCV}$ treatment has been shown to reduce both clinical [21] and economic [22] EHM-related burden. A post-hoc analysis of phase 3 clinical trials revealed that DAA treatment improved multiple EHM biomarkers such as triglycerides (cardiovascular EHM biomarker), serum glucose (metabolic EHM biomarker), and the estimated glomerular filtration rate (renal EHM biomarker). Moreover, these effects lasted for at least a year post-treatment completion [21]. Economic analysis of a large US claims database showed that HCV treatment reduced EHM-related costs by $\$ 12,773$ (or approximately $€ 10,295)$. Additionally, starting treatment at an early disease stage reduced EHM-related costs by $\$ 10,409$ (or approximately $€ 8389$ ) [22].

The economic burden of CHC-related EHCs is not yet fully understood, given that most studies report on a limited number of EHCs [23]. Moreover, the economic impact of CHC-related EHCs in Germany has not been estimated in the 
literature. Therefore, the aim of this study was to utilize a comprehensive national database from the German Betriebskrankenkasse (BKK) sickness fund to assess the role of treatment in mitigating the economic burden of $\mathrm{CHC}$, both hepatic and extrahepatic, especially at early (i.e., non-cirrhotic) stages of liver disease.

\section{METHODS}

\section{Data Sources}

The BKK sickness fund was originally meant for employees of a certain organization; however, since the 1990s, mergers between multiple funds and open enrollment for individuals have broadened the original conception of the BKK [24]. As of 2012, reimbursement data from the BKK sickness fund cover 5.2 million persons and include patients' medical (i.e., in- and outpatient claims), prescription drug, and insurance eligibility information. Data from 2007 through 2014 were utilized for HCV-diagnosed patients. The BKK was informed about the project, and all the required approvals were obtained. Patient data were fully anonymized according to the accepted standard procedures.

\section{Study Definitions}

Prevalent patients with $\mathrm{CHC}$ were identified using the International Classification of Diseases, 10th Edition German Modification (ICD-10-GM) code B18.2 in outpatient and/or inpatient care data in any of the quarters in the identification period (Q1/2008 through Q1/2014). Only patients with a diagnosis of CHC preceded and followed by at least four quarters of full insurance were considered for inclusion. For inpatient data, primary $\mathrm{CHC}$ discharge diagnoses as well as secondary diagnoses were checked. For outpatient data, only assured diagnoses (marked by "G" or " $Z$ ") were considered and also required evidence of a second diagnosis code within three quarters pre- or postidentification. $^{1}$

\footnotetext{
$\overline{1}$ G (abbreviation for "gesicherte Diagnose") = assured
} diagnosis; Z ("Zustand nach") = condition after.

\section{Extrahepatic Complications (EHCs)}

EHCs included EHMs, which have a documented clinical pathway in $\mathrm{CHC}$, as well as other conditions and behavioral factors that, although no clinical pathway has been established, are prevalent among the patient population. EHMs investigated in this study included the broader disease categories of T2DM, cardiovascular disease (CVD), fatigue, renal impairment, and malignancies. Other prevalent diseases observed in the patient population were mental and behavioral disorders (due to opioids, multiple drug use, and other psychoactive substances), Parkinson's disease, and some cardiovascular, renal, and other diseases not documented as EHMs. EHMs, behavioral factors, and other prevalent conditions in the population are jointly called EHCs in this study. The complete list of diseases within each grouping and their disease category, as well as their associated ICD-10-GM codes, is presented in Table 1.

\section{Economic Burden Analyses}

\section{Medical Cost Definitions}

Annualized total costs were assessed from the index quarter until the end of patient follow-up, which corresponded to the end of continuous insurance time, based on whether the patient died or switched to another health insurance, or the end of data availability on 31 December 2014. Therefore, while follow-up time may have differed in length across patients, annualizing the costs served to make patients' follow-up time comparable. To quantify (1) the benefits of treatment in reducing economic burden and (2) the benefits of early treatment, annual costs were compared between (1) time post $\mathrm{CHC}$ treatment and time without $\mathrm{CHC}$ treatment for patients with $\mathrm{CHC}$ and (2) $\mathrm{CHC}$ patients that initiated treatment 'early' (i.e., without cirrhosis) vs. 'late' (i.e., with cirrhosis).

The sum of all-cause medical and pharmacy costs is referred to as total cost. All-cause medical costs were further broken down into medical costs related to hepatic and extrahepatic complications. Pharmacy costs were split into 
Table 1 ICD-10-GM codes for extrahepatic complications

\begin{tabular}{lll}
\hline Condition category & ICD-10- & Label \\
& GM &
\end{tabular}

Extrahepatic manifestations

Type 2 diabetes

E11.* Diabetes mellitus, type 2 [9]

E14.* Diabetes mellitus, not further specified [30]

Cardiovascular disease

I20.*-I25.* Ischemic heart diseases [9]

I60.*-I69.* Cerebrovascular diseases [9]

Fatigue

I70* Atherosclerosis [9]

F32. $\quad$ Episode of depression [9]

G93.3 Chronic fatigue syndrome [31]

R53 Indisposition and fatigue [9]

F43.0 Fatigue in the context of an acute stress reaction, e.g., combat fatigue

F48.0 Neurasthenia

Z73.0 Burnout (state of total exhaustion)

Renal impairment

N18.* Chronic kidney disease [15]

N19.* Renal failure, not further specified [9]

D89.1 Cryoglobulinemia $[30,32]$

Malignancies

C85.* Other and not further specified types of NonHodgkin-lymphoma [22]

Behavioral factors

Mental and behavioral disorders (due to opiods or multiple and other psychoactive substances)

F11.* Mental and behavioral disorders due to use of opioids

F19.* $\quad$ Mental and behavioral disorders due to multiple drug use and use of other psychoactive substances

Conditions that are prevalent in the population

Cardiovascular disease

I10.*-I15.* Hypertension

E78.* Disorders of lipoprotein metabolism and other lipidemias

Parkinson's disease

F02.3 Dementia with primary Parkinson's syndrome

G20.* Primary Parkinson's syndrome

G21.* Secondary Parkinson's syndrome

G22.* Parkinson's syndrome with elsewhere classified diseases

G23.2 Multiple system atrophy of Parkinson type

Renal impairment

N17.* $\quad$ Acute renal failure 
Table 1 continued

\begin{tabular}{lll}
\hline Condition category & $\begin{array}{l}\text { ICD-10- } \\
\text { GM }\end{array}$ & Label \\
\hline Malignancies & C20 & Malign neoplasm of rectum \\
& C22.* & Malign neoplasm of liver and intrahepatic bile ducts \\
& C25.* & Malign neoplasm of pancreas \\
& C34.* & Malign neoplasm of bronchia and lung \\
& C64 & Malign neoplasm of kidney, except from renal pelvis \\
Other & C65 & Malign neoplasm of renal pelvis \\
H52.* & Disorders of refraction and accommodation \\
K29.* & Gastritis and duodenitis \\
M54.* & Dorsalgia \\
\hline
\end{tabular}

ICD-10-GM International Statistical Classification of Diseases and Related Health Problems, 10th revision, German Modification

CHC-related and non-CHC-related costs. CHCrelated costs were defined as those associated with esophageal varices, spontaneous bacterial peritonitis, cirrhosis of the liver, hepatic encephalopathy (liver failure), portal hypertension, ascites, splenomegaly, hepatorenal syndrome, hepatocellular carcinoma, porphyria cutanea tarda, and liver transplantation. Costs attributable to CHC-related EHCs were identified using relevant German Uniform Assessment Standard (EBM) codes, Diagnosis Related Groups (DRG) codes, and Operation and Procedure (OPS) codes. EBM codes are relevant in the setting of medical practitioners, while DRG and OPS codes are relevant in the setting of hospitals (in- and outpatient care). In addition, claims from sickness benefits (medical leave benefits received by employees after 6 weeks of inability to work), which were based on relevant ICD-10-GM codes, were included in the EHC costs. Likewise, medical costs related to hepatic complications were identified by searching for relevant EBM, DRG, OPS, and ICD-10-GM codes associated with hepatic complications. Claims associated with both CHC-associated EHCs and hepatic complications were attributed to both categories. Total all-cause medical costs contain costs for practitioner, hospital in- and outpatient care, as well as sickness benefits. In addition to EHC-related or hepatic complicationrelated medical costs, all other costs that occur because of any disease were included in total allcause medical costs. CHC-related pharmacy costs were identified for $12 \mathrm{CHC}$ drugs, while all other pharmacy costs were summarized as nonCHC-related pharmacy costs (Table 2). Costs were calculated as average annualized charged amounts and adjusted to reflect average 2016 euro exchange rates.

\section{Economic Impact of CHC Treatment}

Treatment was identified by using relevant German Anatomical Therapeutic Chemical (ATC) classification and OPS codes (Table 2). Medical costs between treated and untreated time of patients newly diagnosed with $\mathrm{CHC}$ were compared using data from Q1/2008 to Q4/ 2014. The random quarter of $\mathrm{CHC}$ diagnosis between Q1/2008 to Q4/2014 served as the patients' identification/index quarter and anchored their 4-month lookback and followup. Medical costs for treated time were summarized from the quarter of treatment initiation until end of follow-up. Medical costs for 
Table 2 German anatomical therapeutic chemical, operation, and procedure codes for substances defined as CHC-related pharmacy costs

\begin{tabular}{lll}
\hline ATC code & OPS code & Substance \\
\hline J05AE12 & - & Boceprevir \\
J05AX14 & $6-008 . \mathrm{d}$ & Daclatasvir \\
L03AB** & $8-812.1^{*} / 8-812.2^{*} / 8-547.2$ & Interferon \\
J05AX65 & $6-007 . \mathrm{g}$ (combined with sofosbuvir) & Ledipasvir \\
J05AB04 & - & Ribavirin \\
J05AE14 & $6-008.2$ & Simeprevir \\
J05AX15 & $6-007 . g$ (combined with ledipasvir)/6-008.3 & Sofosbuvir \\
J05AE11 & $6-009.6$ & Telaprevir \\
\hline
\end{tabular}

$A T C$ anatomical therapeutic chemical, $C H C$ chronic hepatitis $\mathrm{C}, O P S$ operation and procedure

untreated time were summarized from the quarter of diagnosis to the end of follow-up or initiation of treatment, whichever came first. Patients that initiated treatment after the quarter of diagnosis contributed data from diagnosis until treatment initiation to untreated time and data to treated time from treatment initiation until end of follow-up. Patients that initiated treatment in the same quarter of diagnosis contributed no data to untreated time while patients that never initiated treatment contributed no data to treated time.

\section{Economic Impact of Early Treatment}

Medical costs for patients diagnosed with $\mathrm{CHC}$ who had received treatment were compared for whether treatment was initiated early or late. Comparison groups were created based on a four-quarter lookback from treatment initiation for evidence of cirrhosis. Patients without evidence of cirrhosis prior to treatment initiation were considered to have had early treatment, whereas those with evidence of cirrhosis prior to treatment initiation were considered to have had late treatment. Cirrhosis was identified using ICD-10-GM codes (K74.3-K74.6).

\section{Statistical Analysis}

Mean cost differences estimated from unadjusted and adjusted ordinary least squares (OLS) regression models were used to compare the medical costs between all study cohorts. Models were adjusted for age (in years), gender, and the previous year's total healthcare costs. Additionally, cost models for treated vs. untreated and early vs. late treatment cohorts were adjusted for their index quarter year. The former comparison was also adjusted for presence of cirrhosis. Mean \pm standard deviation (SD), medians, and proportions were used to depict patient characteristics. Age, gender, and EHM type were independent variables, while the previous year's healthcare costs and current medical costs were dependent variables. All analyses were conducted using SAS version 9.4. Alpha of 0.05 was used as the cutoff for determining statistical significance.

\section{Compliance with Ethics Guidelines}

This article is based on previously available data and does not involve any new studies of human or animal subjects performed by any of the authors. However, appropriate approvals from the BKK were obtained to use their data for this study. 
Similar data were used in a study assessing the clinical and economic burden of hepatic and EHCs associated with CHC in Germany [25]. In that study, CHC was associated with a substantial burden (e.g., medical costs) largely due to hepatic complications and EHCs, subject to limitations similar to those of the present study [25].

\section{RESULTS}

\section{Patient Characteristics}

Of patients with $\mathrm{CHC}, 1714$ were identified as ever receiving treatment $[61.4 \%$ male, average age 45.6 years $(S D=12.2)]$ and 7124 were identified as ever being untreated [54.9\% male, average age 52.6 years $(S D=16.8)]$. Among the treated patients, 1552 received treatment early [61.5\% male, average age 44.5 years $(\mathrm{SD}=12.0)]$ and 162 received treatment late [60.5\% male, average age 55.5 years $(S D=8.9)$, Table 3$]$.

\section{Association between Treatment and Economic Burden}

The economic burden from CHC-related hepatic complications and EHCs was reduced after initiating treatment. Annual medical costs related to hepatic complications ( $€ 1384$ vs. $€ 1022$, adjusted difference $€ 398$ ) and EHCs ( $€ 3573$ vs. $€ 2287$, adjusted difference $€ 1363)$ were significantly higher during the untreated time than the treated time $(P<0.01$ for all; Table 4). However, the average annual total costs $(€ 15,843$ vs. $€ 8206$, adjusted difference $-€ 2125 ; P=0.01)$ and non-HCV-related pharmacy costs ( $€ 7174$ vs. $€ 2243$, adjusted difference $€ 342 ; P=0.70)$ were higher during the treated time. The $€ 1363$ saved in EHC-related medical costs (adjusted cost difference between untreated and treated time) by patients in treatment was a major contributor to the allcause medical cost savings observed (72.3\%). However, both hepatic complication- (€3761 vs. $€ 779$, adjusted difference $€ 2822$ ) and EHC-related costs ( $€ 4561$ and $€ 2085$, adjusted difference $€ 2255$ ) were significantly higher for the late than the early treatment cohort, $(P<0.01$ for both; Table 5). Savings due to EHC-related medical costs were again a major contributor to the savings from early treatment observed in allcause medical (66.5\%) and total (58.9\%) adjusted cost differences.

\section{DISCUSSION}

Using German BKK sickness fund data, for the first time, the all-cause medical, pharmacy, hepatic complication- and EHC-related medical costs were compared between $\mathrm{CHC}$ patients' time of treatment and non-treatment as well as between $\mathrm{CHC}$ patients treated early and late. The results showed that $\mathrm{CHC}$ treatment may significantly mitigate the economic burden of hepatic and EHCs, especially if initiated early. The results concerning the economic burden associated with $\mathrm{CHC}^{\prime}$ s late treatment were consistent with recent evidence from the US [22].

CHC treatment saved $€ 1885$ in all-cause medical costs per patient per year, mainly because of the reduced EHC-related medical costs (adjusted annual cost differences, €1363), but average annual total costs and non-HCV related pharmacy costs were higher during the treated time. Moreover, early treatment of $\mathrm{CHC}$ could save $€ 3831$ in total costs, which includes $€ 3394$ of all-cause medical costs and $€ 2255$ in EHC-related costs, compared with late treatment.

Benefits of $\mathrm{CHC}$ treatment can be experienced both clinically and economically. CHC treatment reduces the number of hepatocellular carcinoma and decompensated cirrhosis cases [18], which results in economic savings. Furthermore, DAA treatment costs can be offset by the benefits incurred within a few years $[19,22]$. On the clinical side, some benefits of $\mathrm{CHC}$ treatment include seroconversion of anti-HCV, normalization of biologic enzymes, reduction of the risk of cirrhosis or even cirrhosis reversion, reduction of liver cancer progression, disappearance of sexual or perinatal transmission risk, improved quality of life, improvement of any EHM, and reduced risk of death [26]. Therefore, it makes sense to tackle $\mathrm{CHC}$ as early 
Table 3 Comparison of patient characteristics between study cohorts

\begin{tabular}{|c|c|c|c|c|}
\hline \multirow[t]{2}{*}{ Characteristics } & \multicolumn{2}{|c|}{$\begin{array}{l}\text { Patients with newly diagnosed } \\
\text { CHC }\end{array}$} & \multicolumn{2}{|c|}{$\begin{array}{l}\text { Treated patients with newly diagnosed } \\
\text { CHC }\end{array}$} \\
\hline & $\begin{array}{l}\text { Treated time, } \\
n=1714\end{array}$ & $\begin{array}{l}\text { Untreated time, } \\
n=7124\end{array}$ & $\begin{array}{l}\text { Early treatment } \\
\text { cohort, } n=1552\end{array}$ & $\begin{array}{l}\text { Late treatment } \\
\text { cohort, } n=162\end{array}$ \\
\hline Age (years), mean $\pm S D$ [median] & $45.6 \pm 12.2[46]$ & $\begin{array}{l}52.6 \pm 16.8 \\
{[51]}\end{array}$ & $44.5 \pm 12.0[45]$ & $55.5 \pm 8.9[55]$ \\
\hline Males, $n(\%)$ & $1052(61.4 \%)$ & $3910(54.9 \%)$ & $954(61.5 \%)$ & $98(60.5 \%)$ \\
\hline $\begin{array}{l}\text { Previous years cost (euros) category } \\
\text { mean } \pm \mathrm{SD} \text { [median] }\end{array}$ & $\begin{array}{l}10,114 \pm 40,915 \\
\quad[3309]\end{array}$ & $\begin{array}{l}6719 \pm 24,004 \\
{[2038]}\end{array}$ & $\begin{array}{l}9652 \pm 41,122 \\
{[3246]}\end{array}$ & $\begin{array}{l}14,544 \pm 38,709 \\
\quad[3749]\end{array}$ \\
\hline \multicolumn{5}{|c|}{ Previous year's healthcare cost (euros) category, $n$ (\%) } \\
\hline 0 & 0 & 0 & 0 & 0 \\
\hline 1st quartile & 922 & 600 & 897 & 1167 \\
\hline 2nd quartile & 3309 & 2038 & 3246 & 3749 \\
\hline 3rd quartile & 12,455 & 6373 & 12,378 & 13,566 \\
\hline 4th quartile & 1508,911 & 1239,866 & 1508,911 & 406,296 \\
\hline \multicolumn{5}{|l|}{ Index year, $n(\%)$} \\
\hline 2008 & $396(23.1 \%)$ & $3191(44.8 \%)$ & $363(23.4 \%)$ & $33(20.4 \%)$ \\
\hline 2009 & $278(16.2 \%)$ & $891(12.5 \%)$ & $261(16.8 \%)$ & $17(10.5 \%)$ \\
\hline 2010 & $238(13.9 \%)$ & $758(10.6 \%)$ & $215(13.9 \%)$ & $23(14.2 \%)$ \\
\hline 2011 & $295(17.2 \%)$ & $790(11.1 \%)$ & $274(17.7 \%)$ & $21(13.0 \%)$ \\
\hline 2012 & $267(15.6 \%)$ & $722(10.1 \%)$ & $228(14.7 \%)$ & $39(24.1 \%)$ \\
\hline 2013 & $175(10.2 \%)$ & $617(8.7 \%)$ & $160(10.3 \%)$ & $15(9.3 \%)$ \\
\hline 2014 & $65(3.8 \%)$ & $155(2.2 \%)$ & $51(3.3 \%)$ & $14(8.6 \%)$ \\
\hline
\end{tabular}

$C H C$ chronic hepatitis $\mathrm{C}$ virus infection, $S D$ standard deviation

as possible. Sbarigia et al. [27] studied the economic value of expanding the HCV treatment capacity in Germany and reported that increasing treatment capacity would reduce disease transmission and prevalence in addition to increasing quality-adjusted life years and net treatment savings.

Using a US claims database, Reau et al. [22] demonstrated that EHMs contributed to the overall economic burden of HCV and its treatment. Of the EHMs assessed, kidney disease and CVD were the costliest EHMs across all comparisons (treated $\mathrm{HCV}$ vs. untreated $\mathrm{HCV}$ and early HCV treatment vs. late $\mathrm{HCV}$ treatment).
The results observed in our study are comparable to Reau et al.'s US study, with the share of the all-cause medical costs attributable to EHCs being $72.3 \%$ for treated vs. untreated time and $66.5 \%$ for early vs. late HCV treatment. It should also be noted that economic modeling may not always reflect real-life conditions, such as the evidence observed in the current study. In this study, early treatment was associated with savings of $€ 3831$ for total costs, with $€ 2255$ saved in EHC-related medical costs alone. Economic modeling in the Spanish [28] and Italian [29] settings have echoed similar conclusions. 
Table 4 All-cause, hepatic complication-related, and extrahepatic complication-related annual costs for treated vs. untreated time

\begin{tabular}{|c|c|c|c|c|}
\hline \multirow[t]{2}{*}{ Cost category } & \multicolumn{3}{|c|}{$\begin{array}{l}\text { Weighted mean costs ( } 2016 \text { euro) per patient per year of } \\
\text { treated and untreated time }\end{array}$} & \multirow{2}{*}{$\begin{array}{l}\text { Adjusted cost } \\
\text { difference }(95 \% \mathrm{CI}) \\
{[B]-[A]^{\mathrm{a}}}\end{array}$} \\
\hline & $\begin{array}{l}\text { Treated } \\
\text { time }[A], \\
N=1714\end{array}$ & $\begin{array}{l}\text { Untreated } \\
\text { time }[B] \\
N=7124\end{array}$ & $\begin{array}{l}\text { Mean cost difference between } \\
\text { untreated and treated time } \\
(95 \% \mathrm{CI})[B]-[A]\end{array}$ & \\
\hline $\begin{array}{l}\text { Total cost (all-cause } \\
\text { medical }+ \text { pharmacy }) \\
(\text { mean } \pm S D)\end{array}$ & $\begin{array}{l}15,842.5 \\
\pm 173,555.5\end{array}$ & $\begin{array}{l}8206.1 \\
\pm 47,770.1\end{array}$ & $\begin{array}{l}-7636.5^{*} \\
(-11,715.9 ;-3557.0)\end{array}$ & $\begin{array}{l}-2124.9^{\#} \\
(-3759.6 ;-490.2)\end{array}$ \\
\hline Total all-cause medical costs & $\begin{array}{l}4243.9 \\
\pm 16,553.2\end{array}$ & $\begin{array}{l}5962.9 \\
\pm 22,398.3\end{array}$ & $\begin{array}{l}1719.0^{*} \\
(1259.8 ; 2178.2)\end{array}$ & $\begin{array}{l}1885.5^{*} \\
(1339.1 ; 2431.8)\end{array}$ \\
\hline $\begin{array}{l}\text { Hepatic complication-related } \\
\text { medical costs }\end{array}$ & $\begin{array}{l}1022.2 \\
\pm 10,263.3\end{array}$ & $\begin{array}{l}1384.3 \\
\pm 10,870.8\end{array}$ & $\begin{array}{l}362.1^{*} \\
(94.1 ; 630.1)\end{array}$ & $\begin{array}{l}397.9^{*} \\
(199.1 ; 596.7)\end{array}$ \\
\hline $\begin{array}{l}\text { Extrahepatic complication- } \\
\text { related medical costs (any of } \\
\text { the conditions listed below) }\end{array}$ & $\begin{array}{l}2287.1 \\
\pm 12,015.6\end{array}$ & $\begin{array}{l}3572.9 \\
\pm 15,999.0\end{array}$ & $\begin{array}{l}1285.8^{*} \\
(954.1 ; 1617.6)\end{array}$ & $\begin{array}{l}1363.2^{*} \\
(1044.0 ; 1682.5)\end{array}$ \\
\hline Type 2 diabetes & $\begin{array}{l}577.8 \\
\pm 6357.2\end{array}$ & $\begin{array}{l}1134.8 \\
\pm 8734.1\end{array}$ & $\begin{array}{l}557.0^{*} \\
(379.8 ; 734.1)\end{array}$ & $\begin{array}{l}409.1^{*} \\
(259.8 ; 558.4)\end{array}$ \\
\hline Cardiovascular disease & $\begin{array}{l}630.0 \\
\pm 7592.2\end{array}$ & $\begin{array}{l}1191.7 \\
\pm 9305.9\end{array}$ & $\begin{array}{l}561.6^{*} \\
(356.7 ; 766.6)\end{array}$ & $\begin{array}{l}442.5^{*} \\
(272.3 ; 612.6)\end{array}$ \\
\hline Parkinson's disease & $\begin{array}{l}380.0 \\
\pm 4914.3\end{array}$ & $\begin{array}{l}587.2 \\
\pm 5216.9\end{array}$ & $\begin{array}{l}207.2^{\#} \\
(78.8 ; 335.6)\end{array}$ & $167.5^{*}(55.2 ; 279.7)$ \\
\hline Mental or behavioral disorders & $\begin{array}{l}777.1 \\
\pm 4071.6\end{array}$ & $\begin{array}{l}1202.9 \\
\pm 7030.6\end{array}$ & $\begin{array}{l}425.8^{*} \\
(302.9 ; 548.8)\end{array}$ & $\begin{array}{l}748.4^{*} \\
(620.9 ; 875.9)\end{array}$ \\
\hline Fatigue & $\begin{array}{l}524.3 \\
\pm 3474.5\end{array}$ & $\begin{array}{l}693.7 \\
\pm 4869.8\end{array}$ & $\begin{array}{l}169.5^{*} \\
(72.1 ; 266.9)\end{array}$ & $\begin{array}{l}429.2^{*} \\
(326.9 ; 531.6)\end{array}$ \\
\hline Renal impairment & $\begin{array}{l}731.2 \\
\pm 8428.8\end{array}$ & $\begin{array}{l}1178.3 \\
\pm 1,0953.3\end{array}$ & $\begin{array}{l}447.1^{*} \\
(215.9 ; 678.2)\end{array}$ & $\begin{array}{l}322.6^{*} \\
(113.0 ; 532.1)\end{array}$ \\
\hline Malignancies & $\begin{array}{l}854.0 \\
\pm 7735.8\end{array}$ & $\begin{array}{l}1236.2 \\
\pm 8438.3\end{array}$ & $\begin{array}{l}382.1^{*} \\
(178.9 ; 585.4)\end{array}$ & $\begin{array}{l}299.1^{*} \\
(127.8 ; 470.5)\end{array}$ \\
\hline Other & $\begin{array}{l}554.5 \\
\pm 6420.1\end{array}$ & $\begin{array}{l}894.5 \\
\pm 7398.2\end{array}$ & $\begin{array}{l}340.0^{*} \\
(169.2 ; 510.7)\end{array}$ & $\begin{array}{l}261.0^{*} \\
(129.1 ; 392.8)\end{array}$ \\
\hline All pharmacy costs & & & & \\
\hline CHC-related pharmacy costs & $\begin{array}{l}4424.3 \\
\quad \pm 10,319.9\end{array}$ & - & - & - \\
\hline
\end{tabular}


Table 4 continued

\begin{tabular}{lllll}
\hline Cost category & \multicolumn{3}{l}{$\begin{array}{l}\text { Weighted mean costs (2016 euro) per patient per year of } \\
\text { treated and untreated time }\end{array}$} & $\begin{array}{l}\text { Adjusted cost } \\
\text { difference }(95 \% \mathbf{C I})\end{array}$ \\
\cline { 2 - 5 } & $\begin{array}{l}\text { Treated } \\
\text { time }[\boldsymbol{A}],\end{array}$ & $\begin{array}{l}\text { Untreated } \\
\text { time }[\boldsymbol{B}],\end{array}$ & $\begin{array}{l}\text { Mean cost difference between } \\
\text { untreated and treated time }\end{array}$ & \\
& $\boldsymbol{N}=\mathbf{1 7 1 4}$ & $\boldsymbol{N}=\mathbf{7 1 2 4}$ & $(\mathbf{9 5 \%} \mathbf{C I})[\boldsymbol{B}]-[\boldsymbol{A}]$ & \\
\hline \multirow{2}{*}{$\begin{array}{l}\text { Non-CHC-related pharmacy } \\
\text { costs }\end{array}$} & 7174.3 & 2243.2 & $-4931.1^{\#}$ & 341.9 \\
\hline
\end{tabular}

$C H C$ chronic hepatitis $\mathrm{C}$ virus infection, $C I$ confidence interval, $O L S$ ordinary least squares, $S D$ standard deviation ${ }^{*} P<0.01,{ }^{\#} P=0.02$

${ }^{a}$ Weighted OLS regression models to estimate adjusted mean cost difference between the treated and untreated follow-up time

The strength of our study is the inclusion of a broad range of EHCs, including some that have not been studied extensively (e.g., mental disorders, gastric disorders), which enabled us to understand the clinical and economic burden of CHC in Germany. EHC is a broader term than EHM because the former only encompasses conditions that have a documented clinical pathway to $\mathrm{CHC}$, while the latter also includes conditions that are prevalent among the patient population but are not yet shown to be related to $\mathrm{CHC}$. Analyzing pharmacy cost data separately from the medical expenditure is another advantage of this study. In fact, the observed higher total cost for CHC treatment compared with non-treatment is attributable to CHC-related pharmacy costs, which by definition the latter cohort did not have.

\section{Limitations}

The limitations of the current study must be kept in mind while interpreting the results. The BKK data only represent $\sim 8 \%$ of all people within the statutory health insurance system. Residual confounding may persist despite sample matching and covariate adjustment in the analyses. Patients could be misclassified because of misinterpretation of the EBM, DRG, OPS, and ICD-10-GM codes. CHC is a chronic disease; hence, a possibility of lag between infection and diagnosis cannot be excluded. Some EHC categories such as cardiovascular disorders and renal impairment are comprised of both EHMs documented in the literature and other conditions that are prevalent in this population. The medical costs were measured as charged amounts, not paid amounts, which may result in overestimation of the actual cost. However, this is likely to affect all the cohorts equally. In addition, a single medical claim could be associated with multiple procedure codes, resulting in the same medical cost being counted under multiple EHM categories. However, these costs were only included once while performing summation. Also, not all EHCs were included in the analysis, and those included were grouped together-this could affect the respective cost analyses. Moreover, data are used from a large span of time (2007-2014), which introduces a high level of heterogeneity regarding patient characteristics and treatment options, making interpretation of the data and results more difficult. However, the results are robust to show that costs incurred during $\mathrm{CHC}$ treatment are less than when $\mathrm{CHC}$ is not being treated for all costs considered in this study. In addition, the analyses included CHC treatments available between 2007 and 2014, but there has been a rapid evolution in the treatment landscape since. Finally, the comparisons between patients receiving early vs. late treatment should be interpreted with caution as those receiving late treatment could include patients with end-stage liver disease, a life-threatening 
Table 5 All-cause, hepatic complication-related, and extrahepatic complication-related annual costs among patients in the early vs. late treatment cohorts

\begin{tabular}{|c|c|c|c|c|}
\hline \multirow[t]{2}{*}{ Cost category } & \multicolumn{3}{|c|}{$\begin{array}{l}\text { Weighted mean costs ( } 2016 \text { euro) per patient per year of } \\
\text { follow-up after treatment initiation }\end{array}$} & \multirow{2}{*}{$\begin{array}{l}\text { Adjusted cost } \\
\text { difference }(95 \% \mathrm{CI}) \\
{[B]-[A]^{\mathrm{a}}}\end{array}$} \\
\hline & $\begin{array}{l}\text { Early CHC } \\
\text { treatment } \\
\text { cohort }[A], \\
N=1552\end{array}$ & $\begin{array}{l}\text { Late CHC } \\
\text { treatment } \\
\text { cohort }[B] \\
N=162\end{array}$ & $\begin{array}{l}\text { Mean cost difference } \\
\text { between late and early } \\
\text { treatment cohorts }(95 \% \mathrm{CI}) \\
{[B]-[A]}\end{array}$ & \\
\hline $\begin{array}{l}\text { Total cost (all-cause } \\
\text { medical }+ \text { pharmacy }) \\
(\text { mean } \pm S D)\end{array}$ & $\begin{array}{l}15,092.3 \\
\pm 181,540.5\end{array}$ & $\begin{array}{l}24,295.7 \\
\pm 52,098.6\end{array}$ & $\begin{array}{l}9203.4^{* *} \\
(3066.0 ; 15,340.7)\end{array}$ & $\begin{array}{l}3831.1 \\
(-3036.0 ; 10,698.2)\end{array}$ \\
\hline Total all-cause medical costs & $\begin{array}{l}3931.4 \\
\pm 13,916.7\end{array}$ & $\begin{array}{l}7765.5 \\
\pm 31,641.6\end{array}$ & $\begin{array}{l}3834.1^{* *} \\
(1212.1 ; 6456.2)\end{array}$ & $\begin{array}{l}3393.5^{* *} \\
(1318.6 ; 5468.5)\end{array}$ \\
\hline $\begin{array}{l}\text { Hepatic complication- } \\
\text { related medical costs }\end{array}$ & $\begin{array}{l}779.1 \\
\pm 6678.7\end{array}$ & $\begin{array}{l}3760.8 \\
\pm 25,724.6\end{array}$ & $\begin{array}{l}2981.7^{* *} \\
(861.4 ; 5102.0)\end{array}$ & $\begin{array}{l}2821.8^{* *} \\
(1323.7 ; 4319.9)\end{array}$ \\
\hline $\begin{array}{l}\text { Extrahepatic complication- } \\
\text { related medical costs (any } \\
\text { of the conditions listed } \\
\text { below) }\end{array}$ & $\begin{array}{l}2085.3 \\
\quad \pm 11,023.2\end{array}$ & $\begin{array}{l}4560.8 \\
\pm 18,583.4\end{array}$ & $\begin{array}{l}2475.5^{* *} \\
(925.3 ; 4025.8)\end{array}$ & $\begin{array}{l}2255.4^{* *} \\
(880.0 ; 3630.8)\end{array}$ \\
\hline Type 2 diabetes & $\begin{array}{l}508.1 \\
\pm 6363.3\end{array}$ & $\begin{array}{l}1363.3 \\
\pm 6124.9\end{array}$ & $\begin{array}{l}855.3^{* *} \\
(329.0 ; 1381.5)\end{array}$ & $\begin{array}{l}716.3^{*} \\
(169.3 ; 1263.3)\end{array}$ \\
\hline Cardiovascular disease & $\begin{array}{l}517.3 \\
\pm 6498.4\end{array}$ & $\begin{array}{l}1900.6 \\
\pm 14,147.7\end{array}$ & $\begin{array}{l}1383.4^{\#} \\
(210.1 ; 2556.6)\end{array}$ & $\begin{array}{l}1233.7^{*} \\
(294.9 ; 2172.5)\end{array}$ \\
\hline Parkinson's disease & $\begin{array}{l}336.6 \\
\pm 4305.9\end{array}$ & $\begin{array}{l}869.8 \\
\pm 8797.8\end{array}$ & $\begin{array}{l}533.2 \\
(-197.2 ; 1263.7)\end{array}$ & $\begin{array}{l}536.3 \\
(-152.3 ; 1224.9)\end{array}$ \\
\hline $\begin{array}{l}\text { Mental or behavioral } \\
\text { disorders }\end{array}$ & $\begin{array}{l}775.8 \\
\pm 4083.5\end{array}$ & $\begin{array}{l}791.3 \\
\pm 3968.3\end{array}$ & $\begin{array}{l}15.5 \\
(-325.2 ; 356.2)\end{array}$ & $\begin{array}{l}331.8 \\
(-67.1 ; 730.8)\end{array}$ \\
\hline Fatigue & $\begin{array}{l}523.7 \\
\pm 3478.7\end{array}$ & $\begin{array}{l}530.0 \\
\pm 3444.1\end{array}$ & $\begin{array}{l}6.2 \\
(-289.0 ; 301.5)\end{array}$ & $\begin{array}{l}226.1 \\
(-128.9 ; 581.1)\end{array}$ \\
\hline Renal impairment & $\begin{array}{l}603.5 \\
\pm 7508.1\end{array}$ & $\begin{array}{l}2170.6 \\
\pm 14,309.1\end{array}$ & $\begin{array}{l}1567.1^{*} \\
(377.3 ; 2757.0)\end{array}$ & $\begin{array}{l}1297.8^{* *} \\
(334.5 ; 2261.0)\end{array}$ \\
\hline Malignancies & $\begin{array}{l}705.9 \\
\pm 6250.8\end{array}$ & $\begin{array}{l}2522.6 \\
\pm 15,793.4\end{array}$ & $\begin{array}{l}1816.7^{* *} \\
(510.0 ; 3123.4)\end{array}$ & $\begin{array}{l}1548.5^{* *} \\
(480.7 ; 2616.3)\end{array}$ \\
\hline Other & $\begin{array}{l}417.5 \\
\pm 4738.1\end{array}$ & $\begin{array}{l}2099.1 \\
\pm 14,593.0\end{array}$ & $\begin{array}{l}1681.6^{* *} \\
(476.8 ; 2886.4)\end{array}$ & $\begin{array}{l}1515.6^{* *} \\
(566.2 ; 2465.1)\end{array}$ \\
\hline
\end{tabular}


Table 5 continued

\begin{tabular}{|c|c|c|c|c|}
\hline \multirow[t]{2}{*}{ Cost category } & \multicolumn{3}{|c|}{$\begin{array}{l}\text { Weighted mean costs }(2016 \text { euro) per patient per year of } \\
\text { follow-up after treatment initiation }\end{array}$} & \multirow{2}{*}{$\begin{array}{l}\text { Adjusted cost } \\
\text { difference }(95 \% \mathrm{CI}) \\
{[B]-[A]^{\mathrm{a}}}\end{array}$} \\
\hline & $\begin{array}{l}\text { Early CHC } \\
\text { treatment } \\
\text { cohort }[A], \\
N=1552\end{array}$ & $\begin{array}{l}\text { Late CHC } \\
\text { treatment } \\
\text { cohort }[B] \text {, } \\
N=162\end{array}$ & $\begin{array}{l}\text { Mean cost difference } \\
\text { between late and early } \\
\text { treatment cohorts }(95 \% \mathrm{CI}) \\
{[B]-[A]}\end{array}$ & \\
\hline \multicolumn{5}{|l|}{ All pharmacy costs } \\
\hline $\begin{array}{l}\text { CHC-related pharmacy } \\
\text { costs }\end{array}$ & $\begin{array}{l}4276.9 \\
\pm 10,141.3\end{array}$ & $\begin{array}{l}6085.1 \\
\pm 11,471.7\end{array}$ & $\begin{array}{l}1808.2^{* *} \\
(834.1 ; 2782.2)\end{array}$ & $\begin{array}{l}1020.4^{*} \\
(246.8 ; 1794.0)\end{array}$ \\
\hline $\begin{array}{l}\text { Non-CHC-related } \\
\text { pharmacy costs }\end{array}$ & $\begin{array}{l}6884.0 \\
\pm 180,187.6\end{array}$ & $\begin{array}{l}10,445.1 \\
\pm 38,850.0\end{array}$ & $\begin{array}{l}3561.1 \\
(-1850.6 ; 8972.8)\end{array}$ & $\begin{array}{l}-582.8 \\
(-7719.0 ; 6553.3)\end{array}$ \\
\hline
\end{tabular}

$C H C$ chronic hepatitis $\mathrm{C}$ virus infection, $C I$ confidence interval, $O L S$ ordinary least squares, $S D$ standard deviation

${ }^{\#} P=0.02,{ }^{*} P=0.01,{ }^{* *} P<0.01$

${ }^{a}$ Weighted OLS regression models to estimate adjusted mean cost difference between the early (i.e., without cirrhosis) and late (i.e., with cirrhosis) relative to the time of treatment initiation

complication of $\mathrm{CHC}$ resulting in significant medical costs.

\section{CONCLUSION}

The current study findings reveal that not treating $\mathrm{CHC}$ or delaying treatment to advanced stages of liver disease may result in additional expenditures, mainly due to EHCrelated complications. This burden suggests that an unmet economic need exists for timely initiation of treatment. The results observed in this study may help guide clinical decision making for the improvement of care for patients with $\mathrm{CHC}$, which in turn could lead to significant cost savings for payers and the healthcare system.

\section{ACKNOWLEDGEMENTS}

Funding. Sponsorship for this study and article processing charges were provided by AbbVie Inc. (USA). AbbVie participated in the interpretation of data, review, and approval of the publication. All authors had full access to all of the data in this study and take complete responsibility for the integrity of the data and accuracy of the data analysis.

Medical Writing and Editorial Assistance. Ramu Periyasamy, PhD, and Leo J. Philip Tharappel of Indegene provided medical writing and editing services on behalf of Kantar Health in the development of this publication. Shawna Calhoun, MPH, and Michael J. Doane, $\mathrm{PhD}$, of Kantar Health also provided assistance with writing. AbbVie Inc. provided funding for editorial assistance to Kantar Health.

Authorship. All named authors meet the International Committee of Medical Journal Editors (ICMJE) criteria for authorship for this article, take responsibility for the integrity of the work as a whole, and have given their approval for this version to be published.

Disclosures. Michael R. Kraus is an employee of Hospital Altötting-Burghausen and is a consultant for AbbVie Inc. Marc Pignot is an 
employee of Kantar Health. Stefanie Thönnes is an employee of Team Gesundheit GmbH and conducted work on behalf of Kantar Health. Kantar Health received funds from AbbVie for conducting the study, analysis, and reporting of findings. Yuri Sanchez Gonzalez is an employee of AbbVie and may hold AbbVie stock or stock options. Henning Kleine is an employee of AbbVie and may hold AbbVie stock or stock options.

Compliance with Ethics Guidelines. This article is based on previously available data and does not involve any new studies of human or animal subjects performed by any of the authors. However, appropriate approvals from the BKK were obtained to use their data for this study.

Data Availability. The data sets generated during and/or analyzed during the current study are not publicly available because of protections around the public sharing of private health information.

Open Access. This article is distributed under the terms of the Creative Commons Attribution-NonCommercial 4.0 International License (http://creativecommons.org/licenses/ by-nc/4.0/), which permits any noncommercial use, distribution, and reproduction in any medium, provided you give appropriate credit to the original author(s) and the source, provide a link to the Creative Commons license, and indicate if changes were made.

\section{REFERENCES}

1. World Health Organization. Hepatitis C in the WHO European Region. 2017 July. http://www. euro.who.int/_data/assets/pdf_file/0010/283357/ fact-sheet-en-hep-c-edited.pdf. Accessed Sept 13, 2017.

2. Gower E, Estes C, Blach S, et al. Global epidemiology and genotype distribution of the hepatitis $\mathrm{C}$ virus infection. J Hepatol. 2014;61:S45-57.

3. Poethko-Muller C, Zimmermann R, Hamouda O, et al. Epidemiology of hepatitis A, B, and C among adults in Germany: results of the German Health Interview and Examination Survey for Adults (DEGS1). Bundesgesundheitsblatt Gesundheitsforschung Gesundheitsschutz. 2013;56:707-15.

4. Razavi H, Waked I, Sarrazin C, Myers RP, Idilman R, Calinas $\mathrm{F}$, et al. The present and future disease burden of hepatitis $\mathrm{C}$ virus (HCV) infection with today's treatment paradigm. J Viral Hepat. 2014;21(Suppl 1):34-59.

5. Guidelines for the screening, care and treatment of persons with chronic hepatitis C infection. World Health Organization; 2016. ISBN 978924154961 5.

6. Younossi ZM, Tanaka A, Eguchi Y, et al. The impact of hepatitis $C$ virus outside the liver: evidence from Asia. Liver Int. 2017;37:159-72.

7. Younossi Z, Park H, Henry L, et al. Extrahepatic manifestations of hepatitis $\mathrm{C}$ : a meta-analysis of prevalence, quality of life, and economic burden. Gastroenterology. 2016;150:1599-608.

8. Carrozzo M, Scally K. Oral manifestations of hepatitis C virus infection. World J Gastroenterol. 2014;20:7534-43.

9. Cacoub P, Comarmond C, Domont F, et al. Extrahepatic manifestations of chronic hepatitis $\mathrm{C}$ virus infection. Ther Adv Infect Dis. 2016;3:3-14.

10. Wijarnpreecha K, Chesdachai S, Jaruvongvanich V, Ungprasert P. Hepatitis $C$ virus infection and risk of Parkinson's disease: a systematic review and metaanalysis. Eur J Gastroenterol Hepatol. 2018;30:9-13.

11. Khalsa JH, Treisman G, McCance-Katz E, Tedaldi E. Medical consequences of drug abuse and co-occurring infections: research at the National Institute on Drug Abuse. Subst Abus. 2008;29:5-16.

12. Petta S. Hepatitis $\mathrm{C}$ virus and cardiovascular: a review. J Adv Res. 2017;8:161-8.

13. Balakrishnan M, Glover MT, Kanwal F. Hepatitis C and risk of nonhepatic malignancies. Clin Liver Dis. 2017;21:543-54.

14. Nevens F, Colle I, Michielsen P, et al. Resource use and cost of hepatitis C-related care. Eur J Gastroenterol Hepatol. 2012;24:1191-8.

15. Cacoub P, Buggisch P, Beckerman R, et al. Direct medical costs associated with the extrahepatic manifestations of hepatitis C infection. J Hepatol. 2017;66:S499.

16. Van NK, Brookmeyer R, Chou JW, et al. Broad hepatitis $\mathrm{C}$ treatment scenarios return substantial 
health gains, but capacity is a concern. Health Aff (Millwood.). 2015;34:1666-74.

17. Linthicum MT, Gonzalez YS, Mulligan K, et al. Value of expanding HCV screening and treatment policies in the United States. Am J Manag Care. 2016;22:SP227-35.

18. Younossi ZM, Tanaka A, Eguchi Y, Henry L, Beckerman R, Mizokami M. Treatment of hepatiis C virus leads to economic gains related to reduction in cases of hepatocellular carcinoma and decompensated cirrhosis in Japan. J Viral Hepat. 2018;00:1-7. https://doi.org/10.1111/jvh.12886.

19. Aggarwal R, Chen Q, Goel A, et al. Cost-effectivenss of hepatitis $\mathrm{C}$ treatment using generic direct-acting antivirals available in India. PLoS One. 2017;12:e0176503. https://doi.org/10.1371/ journal.pone.0176503.

20. Rosenthal ES, Graham CS. Price and affordability of direct-acting antiviral regimens for hepatitis $C$ virus in the United States. Infect Agent Cancer. 2016;11:24. https://doi.org/10.1186/s13027-0160071-z.

21. Mehta DA, Cohen E, Charafeddine M, et al. Effect of hepatitis $\mathrm{C}$ treatment with Ombitasvir/Paritaprevir/ $\mathrm{R}+$ Dasabuvir on renal, cardiovascular and metabolic extrahepatic manifestations: a post-hoc analysis of phase 3 clinical trials. Infect Dis Ther. 2017;6:515-29.

22. Reau N, Vekeman F, Wu E, et al. Prevalence and economic burden of extrahepatic manifestations of hepatitis $C$ virus are underestimated but can be improved with therapy. Hepatol Commun. 2017;1:439-52.

23. Solinis RN, Ugarte PA, Rojo A, et al. Value of treating all stages of chronic hepatitis C: a comprehensive review of clinical and economic evidence. Infect Dis Ther. 2016;5:491-508.
24. Greß S, Schut E, Wasem J. Free choice of sickness funds in social health insurance-theoretical foundation and empirical findings in Germany. In: Paper presented at the Fourth European Conference on Health Economics, Paris, 9 July 2002.

25. Kraus MR, Kleine $H$, Thönnes $S$. , et al. Infect Dis Ther. 2018;. https://doi.org/10.1007/s40121-0180204-3.

26. Marinho RT, Vitor S, Velosa J. Benefits of curing hepatitis C infection. J Gastrointest Liver Dis. 2014;23:85-90.

27. Sbarigia U, Wirth D, Van Nuys K, et al. Economic study of the value of expanding HCV treatment capacity in Germany. BMJ Open Gastroenterol. 2017;4:e000130. https://doi.org/10.1136/bmjgast2016-000130.

28. Buti M, Dominguez-Hernandez R, Oyaguez I, et al. Cost-effectiveness analysis of sofosbuvir, peginterferon and ribavirin in patients with chronic hepatitis C: early treatment in the initial stage of fibrosis vs. delayed treatment in advanced fibrosis. Gastroenterol Hepatol. 2016;39:449-57.

29. Marcellusi A, Viti R, Damele F, et al. Early treatment in HCV: is it a cost-utility option from the Italian perspective? Clin Drug Investig. 2016;36:661-72.

30. Tengan FM, Levy-Neto M, Miziara ID, Dantas BP, Maragno L. Extrahepatic manifestations of chronic hepatitis C infection: a consecutive study in Brazilian patients. Braz J Infect Dis. 2017;21:203-4.

31. Mohammed RH, ElMakhzangy HI, Gamal A, et al. Prevalence of rheumatologic manifestations of chronic hepatitis $\mathrm{C}$ virus infection among Egyptians. Clin Rheumatol. 2010;29:1373-80.

32. Cheng Z, Zhou B, Shi X, et al. Extrahepatic manifestations of chronic hepatitis $C$ virus infection: 297 cases from a tertiary medical center in Beijing, China. Chin Med J (Engl). 2014;127:1206-10. 